\title{
Bibliografi Beranotasi Tentang Situs Keraton Ratu Boko
}

\section{Nurhadi Rangkuti}

Keywords: annotated bibliography, mataram, hindu, citations, temples

\section{How to Cite:}

Rangkuti, N. (2003). Bibliografi Beranotasi Tentang Situs Keraton Ratu Boko. Berkala Arkeologi, 23(1), 121-131. https:// doi.org/10.30883/jba.v23i1.867

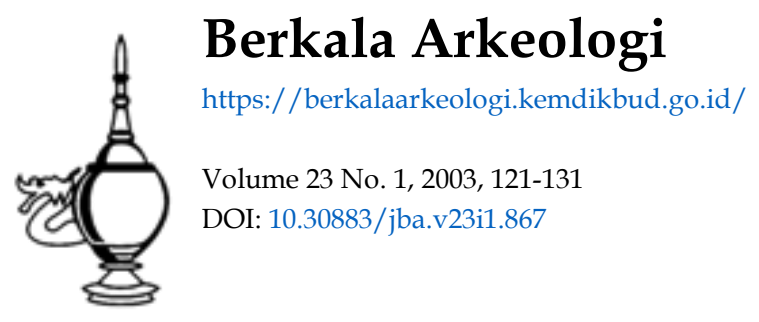

\section{c) (i)(2)}

This work is licensed under a Creative Commons Attribution-NonCommercial-ShareAlike 4.0 International License. 


\title{
BIBLIOGRAFI BERANOTASI \\ TENTANG SITUS KERATON RATU BOKO
}

\author{
Nurhadi Rangkuti
}

\section{$\mathbf{P}$}

\section{engantar}

Situs Keraton Ratu Boko yang terletak di atas bukit di daerah Prambanan, (abad ke-8-10 Masehi). Kompleks percandian ini terdiri dari tiga kelompok bangunan, yaitu (1) Bagian barat, berupa halaman bertingkat tiga. Ketiga halaman tersebut dihubungkan oleh gapura-gapura yang tertutup (paduraksa). Pada halaman-halaman tersebut terdapat sisa-sisa bangunan yang sekarang sudah dipugar, (2) Bagian tenggara, berupa sekelompok bangunan yang terdiri atas dua bagian. Satu bagian berupa lantai batu dengan pagar keliling dari batu. Bangunan ini disebut "pendopo". Bagian lainnya berupa kolam-kolam dengan bangunan-bangunan yang disebut "keputren", dan di sekitarnya terdapat bangunan-bangunan kecil berbentuk candi yang terletak di atas kolam-kolam, (3) bagian timurlaut, merupakan tiga buah gua yang terletak di lereng bukit. Selain ketiga kelompok tersebut, masih banyak peninggalanpeninggalan lain yang bentuk maupun fungsinya tidak jelas.

Di daerah sekitar Ratu Boko pernah ditemukan 10 buah prasasti yang berhuruf Prenagari, Jawa Kuna dengan bahasa Sansekerta dan Sansekerta-Jawa Kuna. Salah satunya adalah prasasti singkat pada lempengan emas ditemukan pada waktu pemugaran tahun 1990. Berdasarkan angka tahun yang tertera pada prasasti dan gaya tulisan pada prasasti yang tidak berangka tahun, diketahui prasasti-prasti tersebut diterbitkan pada abad, VIII - IX Masehi.

Situs Keraton Ratu Boko telah diteliti sejak tahun 1938 oleh van Romondt, dan sampai sekarang kegiatan arkeologi yang meliputi penggalian dan pemugaran masih terus berlangsung. Pada tahun 1991 Situs Keraton Ratu Boko telah ditetapkan menjadi obyek wisata yang berada di bawah PT Taman Wisata Candi Borobudur, Prambanan dan Ratu Boko.

Uraian di bawah ini mengenai bibliografi dari berbagai karya tulis mengenai situs Keraton Ratu Boko. Secara garis besar tulisan-tulisan itu meliputi penelitian, pemugaran dan pengelolaan situs dalam kaitannya dengan pariwisata. 


\section{Rambang Prasetya Wahyuhono dan Wahyu Indrasana, 1993, "Lima Belas D Tahun Pemugaran Situs Ratu Boko" dalam Pertemuan Teknis Dalam Rangka Evaluasi Program Pemugaran Situs Ratu Boko Yogyakarta, 15 halaman}

Pemugaran Situs Ratu Boko sebenarnya telah dilakukan pada tahun 1938 oleh van Romondt yang menampakungkapkan sisa-sisa bangunan di situs tersebut. Beliau berhasil membuat denah dan gambar rekonstruksi Gapura utama I dan II. Bersamaan dengan kegiatan itu dilakukan pula penyusunan percobaan bagian kaki, tubuh, atap saluran air di kanan dan kiri gapura serta pipi tangga. Pada kegiatan selanjutnya dapat diselesaikan gambar rekonstruksi Candi Pembakaran dan denah sekitar Gapura utama I dan II.

Van Romondt digantikan oleh Soehamir pada masa pendudukan Jepang. Pada masa ini dilakukan penyusunan percobaan Candi Pembakaran dan Gapura utama. Kegiatan di Situs Ratu Boko terhenti pada tahun 1945-1948, dan dilanjutkan lagi pada akhir tahun 1948 dan tahun 1949 dengan sasaran Gapura Utama I dan sekitar pendopo dan kolam. Pada tahun 1950 hingga tahun 1954 dilaksanakan pemugaran Gapura utama I dan II hingga selesai. Kegiatan pemugaran tahun 1960-1965 berhasil menyelesaikan gapura kolam.

Pada tahun 1978 hingga 1993 dilakukan pemugaran selama Pembangunan Jangka Panjang Tahap I. Selama jangka waktu tersebut telah dilaksanakan kegiatan penyusunan percobaan dan pemugaran di gapura dan pagar pendopo, batu pendopo, batur pringgitan, selasar pendopo. Selain itu dilakukan pula penggalian-penggalian dan berhasil menemukan arca Ganesha, serta bentuk-bentuk talud, yaitu talud berkaki dan talud tanpa kaki.

Masalah-masalah yang dihadapi selama pemugaran adalah faktor topografi, proses pelapukan dan pelarutan batuan serta genangan air. Situs Ratu Boko terletak pada daerah perbukitan batu gamping yang miring ke selatan dan proses pelapukan dan pelarutan di daerah ini cukup tinggi. Masalah yang perlu diatasi pula adalah masalah pembebasan tanah. Situs Ratu Boko luasnya 168.210 meter persegi. Selama 15 tahun telah dibebaskan tanah seluas 145.554 meter persegi dan sisanya belum dapat dibebaskan mengingat para pemilik tanah menguasakan kepada Lembaga Bantuan Hukum (LBH) Yogyakarta.

\section{Rernet Kempers, A.J. dan Soekmono, 1974, Candi-Candi di Sekitar Drambanan, Bandung: Ganaco N.V. (59 halaman)}

Buku kecil ini menguraikan peninggalan-peninggalan purbakala di sepanjang jalan raya dari Yogya ke Solo atau di dekatnya. Diuraikan lokasi, sejarah ringkas peninggalan purbakala, kondisi peninggalan, serta akses untuk mengunjungi situs-situs 
pada masa itu. Situs-situs yang diuraikan meliputi Candi Kalasan, Candi Sari, Candi Sewu, Candi Plaosan, Candi Sajiwan, dan Ratu Boko.

Khusus mengenai Ratu Boko digambarkan lokasinya berada di dataran tinggi, dari pasar Prambanan kita harus mengambil jalan yang menuju ke selatan. Jalan itu menuju ke kaki sebuah bukit dan dengan menyusur kaki itu kita membelok ke barat, untuk kemudian naik ke atas bukit.

Dikisahkan tentang legenda Ratu Boko. Nama itu merupakan nama seorang raja yang mempunyai puteri bernama Loro Jonggrang. Menurut cerita rakyat runtuhan-runtuhan itu adalah peninggalan-peninggalan bekas keraton Ratu Boko. Bernet Kempers dan Soekmono membenarkan cerita tersebut setelah melihat bentuk-bentuk peninggalan berupa gapura-gapuran dengan alun-alun di depannya, batur pendopo yang cukup luas, dan kolam-kolam untuk menampung air, serta tempat yang disebut "keputren" atau tempat para puteri. Selain itu dijumpai pula bekas-bekas penggalian batu, jenjang-jenjang dan bilik-bilik yang terpahatkan dalam batu.

Bilik-bilik itu menurut ceritanya adalah tempat sang raja mengundurkan diri untuk mengheningkan cipta, kalau ada soal-soal penting yang harus diputuskan. Dari sana kita masih dapat memanjat lebih tinggi lagi. Dari sini kita dapat menikmati pemandangan yang indah terhadap tanah datar yang membentang ke utara, dengan puncak Candi Prambanan atau gugusan Candi Loro Jonggrang yang menjulang ke langit biru bagaikan pegangan arah pandangan.

\section{Rosch, FDK, 1918, Rapporten Oudheidkundigen Dienst (ROD 1915), DWeltevreden: Albrecht \& co. (hal 37-38).}

Pada nomor inventaris 1289 , Bosch menyebut peninggalan candi yang ada di atas bukit daerah Prambanan, sebagai Keraton Ratu Boko. Kompleks keraton ini merupakan sisa-sisa peninggalan Mataram Kuna. Gapura keraton Ratu Boko oleh penduduk setempat disebut Candi Dawong. Pada tahun 1901 ditemukan sebuah prasasti batu berhuruf Prenagari yang kemudian disimpan di Museum Batavia (Museum Nasional) dengan kode D 50.

\section{Djoko Dwiyanto dan J. Susetyo Edy Yuwono, 1996. "Laporan Penelitian Arkeologi Kawasan Kraton Ratu Boko", Yogyakarta: Pusat Penelitian Pariwisata Univ. Gadjah Mada.}

Penelitian dilakukan pada tahun 1996 dengan tujuan untuk menemuungkapkan data arkeologi di kawasan Ratu Boko dan memberikan bahan pertimbangan dalam rangka konservasi-preservasi terhadap kawasan Ratu Boko. Sasaran penelitian antara lain pengujian terhadap penetapan pemintakatan (zoning) yang telah ditentukan 
sebelumnya, dan memberi keyakinan tentang potensi tinggalan purbakala di mintakat II (zone penyangga Intensif-Ekstensif) yang perlu dipertimbangkan keberadaan dan kelestariannya.

Hasil penelitian menunjukkan bahwa potensi arkeologi ada yang sangat tinggi, tidak tinggi dan potensi yang rendah, terdapat pada sejumlah sektor. Untuk sektor yang memiliki potens arkeologi tinggi, direkomendasi agara rencana pembangunan fasilitas fisik penunjang pariwisata di sektor-sektor berpotensi tinggi tersebut sangat perlu dipertimbangkan lagi pelaksanaannya. Sektor-sektor yang memiliki potensi arkeologi yang sangat tinggi antara lain di Sektor Pentas Kesenian dan Sektor Gapura, sedangka potensi arkeologi yang tidak begitu tinggi terdapat di Sektor Kolam, Plaza, Tempat Parkir, Laboratorium Budaya, Pengelola Taman Wisata, dan Restoran/mushola, Rekomendasi yang diberikan untuk sektor-sektor yang memiliki potensi arkeologi yang tidak begitu tinggi adalah rencana pembangunan fasilitas pariwisata dapat dilanjutkan, namun perlu diusahakan agar pembuatan lantai dan sarana jalan memperhatikan tersedianya ruang-ruang tertentu yang masih memungkinkan dilaksanakannya penelitian arkeologi di kemudian hari.

\section{Dukut Santoso, 1993, "Rencana Pemugaran Situs Ratu Boko Selama Repelita VI" dalam Pertemuan Teknis Dalam Rangka Evaluasi Program Pemugaran Situs Ratu Boko Yogyakarta 19-23 Juli 1993, 22 halaman}

Pada prinsipnya pemugaran bangunan cagar budaya dilaksanakan berdasarkan elemen-elemen asli yang masih ada. Namun kenyataan di lapangan tidak dapat dihindari adanya tambahan elemen dan juga perkuatan dengan struktur baru di dalam bangunan, sehingga memungkinkan adanya toleransi dalam pengambilan keputusan tersebut.

Dalam kaitannya dengan pemugaran Situs Ratu Boko, sebaiknya dipugar bila bangunan-bangunan tersebut sudah dibuat rekonstruksinya di atas kertas. Namun hal tersebut berbeda dalam pelaksanaan di Ratu Boko. Meskipun pemugarannya sudah berlangsung selama 15 tahun (1978-1993), namun hasil keseluruhan yang akan dicapai nantinya belum ada gambaran yang jelas.

Ada enam kriteria bangunan yang ditinjau dari segi kondisi setiap gugusan bangunan tersebut, yaitu 1) gugusan bangunan yang sudah berhasil dipugar keseluruhan; 2) gugusan bangunan yang baru dipugar sebagian karena selebihnya masih terpendam tanah dan areanya belum dibebaskan; 3) gugusan bangunan yang tampak di atas permukaan tanah dan telah dilakukan prapemugaran; 4) gugusan bangunan yang sudah tampak di permukaan tanah tetapi belum dilakukan prapemugaran, namun areanya sudah dibebaskan; 5) gugusan bangunan yang sudah tampak di atas permukaan tanah tetapi areanya belum dibebaskan; dan 6) gugusan bangunan yang 
bentuk dan polanya masih dalam perkiraan atas dasar interpretasi di lapangan, karena masih dalam tanah.

Berdasarkan enam kriteria tersebut, perlu tahapan pemugaran Situs Ratu Boko, sehingga dapat ditentukan urutan prioritasnya dan diharapkan tidak akan terjadi kendala-kendala yang sama seperti tahun lalu.

\section{Hari Untoro Drajat dan Ismijono, 1993. "Tinjauan Penanganan Situs Ratu Boko" dalam Pertemuan Tekuis Dalam Rangka Evaluasi Program Pemugaran Situs Ratu Boko Yogyakarta, 9 halaman.}

Ditinjau dari keletakannya secara geografis, bukit Ratu Boko merupakan suatu kesatuan budaya dari rangkaian candi-candi sekitarnya, seperti gugusan Candi Prambanan, Candi Sewu, Candi Plaosan, Candi Sajiwan dan sebagainya. Keadaan serupa itu menjadikan situs Ratu Boko termasuk dalam "Group Monument" atau suatu kelompok yang terdiri dari beberapa bangunan yang terintegrasi dalam bentuk pola yang teratur dalam satu asosiasi pada bidang lahan yang cukup luas. Potensi Situs Ratu Boko yang demikian dapat dikategorikan sebagai "relict landscape".

Sebelum pemugaran dimulai, sebaiknya diupayakan penggalian secara menyeluruh (total excavation). Namun usaha ini belum dilakukan di Situs Ratu Boko, mengingat situs Ratu Boko ini memiliki lahan yang luas. Sebaiknya pula untuk mendukung kelestarian Situs Ratu Boko, diperlukan seperangkat ketentuan mendasar, yaitu:

- Keaslian bahan (authenticity in material)

- Keaslian desain (authenticity in desing)

- Keaslian lingkungan (authenticity in setting)

- Keaslian pembuatan (authenticity in workmanship).

Saran yang perlu diperhatikan dalam menangani Situs Ratu Boko, antara lain:

1. Kegiatan utama di Ratu Boko adalah mewujudkan suatu pemugaran yang berwawasan pemanfaatan melalui perencanaan secara sistematis sesuai dengan prosedur yang berlaku (studi kelayakan/masterplan)

2. Menentukan skala prioritas penanganannya atas dasar hasil studi

3. Penjadwalan secara jelas dari setiap kegiatan dalam rangka pemugaran/penataan situs Ratu Boko

4. Perlu melibatkan berbagai sektor lain secara aktif untuk mewujudkan pelestarian dan pemanfaatannya.

5. Hendaknya lahan situs dapat ditentukan peringkat potensinya sehingga dapat tetap pada kondisi aslinya untuk kepentingan fasilitas yang dibutuhkan saat ini.

6. Penetapan status pemilikan lahan yang beragam di kawasan Ratu Boko perlu segera ditata kejelasannya, terutama penetapan dalam bentuk peringkat yang didasarkan bagi kepentingan pelestarian dan pemanfaatan. 


\section{T usen, 1995, Kompleks Ratu Boko: Latar Belakang Pemilihan Tempat dan Pembangunannya, dalam Berkala Arkeologi Edisi Khusus. Yogyakarta: Balai Arkeologi, (hal 128-133).}

Artikel ini membahas tentang latar belakang sejarah dan fungsi Kompleks Keraton Ratu Boko. Kompleks Ratu Boko semula merupakan sebagai wihara yang bernama Abhayagiri, didirikan oleh Rakai Panangkaran antara tahun 784-792 Masehi. Pada sekitar tahun 856 Masehi kompleks tersebut berubah menjadi keraton seorang penguasa bernama Rakai Walaing Pu Kumbhayoni. Nama tokoh ini disebut dalam Prasasti Pereng tahun $863 \mathrm{M}$. Pada tahun $907 \mathrm{M}$ Walaing sebagai nama tempat disebut dalam Prasasti Mantyasih.

Kompleks Ratu Boko meskipun terletak di atas bukit yang potensi sumberdaya lingkungannya rendah, namun ditinjau dari segi keletakannya memiliki tingkat aksesibilitas yang cukup tinggi dan relatif dekat dengan area yang subur serta padat penduduknya. Hal inilah yang menjadi pertimbangan Rakai Panangkaran ketika membangun wihara di atas bukit Ratu Boko. Sebab seperti diketahui, kehidupan para bhiksu penghuni wihara memerlukan dukungan umat Buddha. Dukungan ini dapat diperoleh dengan mudah jika lokasi wihara tidak jauh dari permukiman penduduk.

Penulis berharap untuk penelitian selanjutnya di Ratu Boko perlu menerapkan teknikteknik pertanggalan mutlak (absolute dating). Hal ini diperlukan antara lain untuk mengetahui periodisasi peninggalan-peninggalan purbakala di Ratu Boko, dan kapan bencana lahar dingin melanda kawasan Prambanan dan sekitarnya.

\section{Ranguti, Nurhadi, 1984 "Pemakaian Batu Tufa pada Candi-Candi di Sekitar
Prambanan" Skripsi S1 Arkeologi, Fakultas Sastra Universitas Indonesia.}

Candi-candi di sekitar Prambanan menggunakan dua jenis bahan, yaitu batu andesit dan batu tufa (tuff). Perbukitan Ratu Boko merupakan sumber bahan batu tufa untuk pembangunan candi-candi, sedangkan batu andesit di peroleh dari lereng Gunung Merapi.

Kajian bertujuan untuk mengetahui pola pemakaian batu tufa pada 29 situs candi yang terdapat di dataran rendah dan dataran tinggi. Dataran tinggi yang dimaksud adalah perbukitan Ratu Boko, dimana terdapat situs-situs candi, yaitu kompleks Keraton Ratu Boko, Situs Candi Miri, Candi Sari (Sorogedug), Candi Ijo, dan Candi Tinjon.

Hasil kajian menggambarkan adanya empat pola pemakaian batu tufa pada candicandi di kawasan Prambanan, yaitu (I) pola pemakaian tetap, (II) pola pemakaian relatif merata; (III) pola pemakaian tidak merata; dan (IV) pola tidak digunakannya batu tufa atau aglomerat. 
Pola I batu tufa digunakan secara tetap pada bangunan pagar ketiga, khususnya untuk pondasi dan batu isian (inner stone), yaitu di kompleks Candi Prambanan, Candi Sambisari dan Candi Sewu. Pola II batu tufa digunakan pada pondasi bangunan candi, baik bangunan utama, bangunan serta, pagar keliling ke-1 dan ke-2. Pola III, batu tufa digunakan untuk Batu kulit atau batu luar candi (outerstone) baik untuk lantai candi, batukulit bangunan serta, dan arca-arca. Pemakaian tersebut khususnya terdapat di perbukitan Ratu Boko atau disebut pula perbukitan Baturagung. Di dataran aluvial, atribut-atribut candi tersebut umumnya menggunakan batu andesit.

Pola IV semua situs candi tidak menggunakan batu tufa tetapi menggunakan batu andesit pada batu kulit (outerstone), termasuk candi-candi yang terdapat di dataran tinggi. Bangunan-bangunan Kompleks Candi Ratu Boko, Candi Ijo dan Candi Barong, juga menggunakan batu andesit untuk batu luarnya. Jenis bahan ini harus diperoleh dari luar bukit.

\section{Qoekmono, 1993, "Ratu Boko Quo Vadis?" dalam Pertemuan Teknis Dalam NRangka Evaluasi Program Pemugaran Situs Ratu Boko Yogyakarta, 10 halaman}

Dalam kaitannya dengan pemugaran Situs Ratu Boko, penulis mengingatkan agar menghindari pemalsuan dan menghindari cap pribadi. Kedua larangan ini tidak dapat dipisahkan dan saling berkaitan. Menambah sesuatu untuk melengkapi kekurangan (biasanya dengan mengambil contoh dari bagian lain yang masih utuh) secara umum tidaklah lain dari upaya si pemugar untuk memenuhi hasrat pribadinya menunaikan tugas sebaik-baiknya. Bahwa hasilnya adalah pemalsuan yang menampilkan cap pribadi disebabkan oleh karena upaya tersebut tidak merupakan tuntutan mutlak dari apa yang dipugar.

Inti dari tulisan ini adalah bahwa pemugaran tidak harus menghasilkan utuhnya kembali bangunan yang dipugar. Penambahan sebagai upaya melengkapi bagian yang kurang tidak perlu dilakukan, meskipun gambar rekonstruksi memberi kemungkinan dan bahkan peluang. Menurut penulis, peninggalan purbakala akan jauh lebih indah dan lebih dapat diserap nilai kepurbakalaannya bilamana dapat ditampilkan sebagai gabungan antara bangunan utuh dan runtuhan, daripada bangunan utuh hasil pemugaran yang tidak dihias dengan tumpukan batu-batu candi.

Untuk pemugaran Ratu Boko yang akan dimanfaatkan sebagai taman purbakala yang bersifat nasional dan bahkan internasional, agar memperhatikan pelestarian lingkungan. Dalam hal ini perlu mengikutsertakan masyarakat sekitar, khususnya pendidikan tentang pelestari peninggalan purbakala. Jadi Ratu Boko sebagai obyek wisata, tidak sekedar tempat rekreasi melainkan menambah ilmu dan memperluas wawasan. 


\section{Subroto, Ph., 1993, "Kegiatan-Kegiatan Penelitian Situs Ratu Boko" dalam Pertemuan Teknis Dalam Rangka Evaluasi Program Pemugaran Situs Ratu Boko Yogyakarta 19-23 Juli 1993, 31 halaman}

Berdasarkan laporan-laporan disebutkan di daerah sekitar Ratu Boko pernah ditemukan 10 buah prasasti yang berhuruf Prenagari, Jawa Kuna dengan bahasa Sansekerta dan Sansekerta-Jawa Kuna. Salah satunya adalah prasasti singkat pada lempengan emas ditemukan pada waktu pemugaran tahun 1990. Dua di antara prasasti-prasasti tersebut isinya berhubungan dengan pendirian bangunan suci untuk Awalokiteswara. Berdasarkan gaya tulisannya, de Casparis, ahli epigrafi, memperkirakan prasasti itu berasal dari abad VIII Masehi sejaman dengan prasasti Kalasan. Tiga prasasti yang berhuruf Jawa Kuna memuat angka tahun Saka 778 (856 Masehi). Satu prasasti berisi tentang pendirian lingga Kerttiwasa, sedang satunya lagi berisi lingga Triambaka atas perintah raja Kumbhaja. Sebuah prasasti yang lain tidak memuat angka tahun, menyebutkan pendirian sebuah lingga Hara atas perintah raja Kalasodbhawa.

Sebuah prasasti ditemukan di desa Pereng, ditulis pada tahun Saka 785 (863 Masehi). Isinya tentang pendirian bangunan suci untuk Dewa Siwa yang bernama Badraloka atas perintah Rakai Walaing pu Kumbhayoni.

Selain penelitian prasasti, penelitian di Situs Ratu Boko dilakukan dengan penggalian arkeologis pada tahun 1973 oleh sebuah tim gabungan antara Lembaga Purbakala dan Peninggalan Nasional dan University of Pennsylvania Museum AS (lihat Teguh Asmar dan Bennet Bronson 1973). Setelah itu penelitian-penelitian dilanjutkan selama pemugaran, yaitu sejak tahun 1978 sampai 1993.

Serangkaian penelitian di Situs Ratu Boko selama pemugaran meliputi arsitektur bangunan, dan fungsi situs yang masih menjadi bahan perdebatan. Apakah Ratu Boko sebagai bekas keraton, taman untuk sebuah keraton, atau bahkan sebagai sebuah vihara. Untuk itu perlu penelitian yang intensif untuk mencari data-data baru tentang karakteristik dan fungsi Ratu Boko.

Dari serangkaian penelitian, menunjukkan bahwa Situs Ratu Boko pernah menjadi pusat pemerintahan. Di situs ini terdapat dua kelompok ruang, yaitu kelompok dalam di bagian sebelah tenggara, dan kelompok luar di bagian baratlaut. Kelompok dalam lebih berfungsi sebagai tempat tinggal raja dan kerabat raja, sedang kelompok luar lebih berfungsi sebagai tempat kerja raja dan tempat mengadakan kontak dengan masyarakat umum. 


\section{Teguh Asmar dan Bennet Bronson, 1973, Laporan Ekskavasi Ratu Baka 1973, Jakarta: Lembaga Purbakala dan Peninggalan Nasional dan The University of Pennsylvania Museum.}

Penelitian arkeologi ini bertujuan untuk mengetahui fungsi Keraton Ratu Baka dan kronologinya. Penggalian arkeologis (ekskavasi) telah berhasil menemukan pecahanpecahan keramik, tembikar (wadah dan genteng), pecahan bata kuna, fragmen logam, sisa-sisa tumbuhan dan hewan (burung, sapi, kerbau, kijang). Keramik-keramik Cina yang ditemukan berasal dari dinasti Song (10-12 M), beberaoa keramik Ming (14-16 M).

Berdasarkan analisis artefak, lapisan tanah, dan didukung oleh prasasti, tim penelitian menyimpulkan bahwa Situs Keraton Ratu Boko difungsikan dalam beberapa periode atau fase. Sedikitnya ada empat fase penghunian yaitu:

Fase IV

1850 - kini Pendudukan masa kini oleh para petani, pemotong batu dan pekerjapekerja purbakala

$1250 / 1400-1850$ Sebagian besar tempat ini kosong ditinggalkan penduduknya.

Fase III

1025/1050 - 1350/1400 Pendudukan oleh para petani, pemotong batu, tukang-tukang (craftmen) dan bebarapa orang yang menggunakan keramik cina.

\section{Fase II}

775/825 - 1025/1050 Diperkirakan penduduk di Ratu Boko terdiri dari sejumlah besar pekerja bangunan, tukang-tukang, pelayan-pelayan dan orang-orang dari kelompok elit yang bukan dari golongan agama. Semua bangunan dibuat dari batu yang terus dilanjutkan sampai fase III. Sebagian besar prasasti-prasasti dibuat pada fase II.

\section{Fase I}

$600 ? / \& 00$ ? - 775/825 Ratu Boko hanya didiami sejumlah kecil penduduk dan terdiri dari pekerja bangunan, pelayan dan beberapa orang dari kelompok elit. Belum dibuat bangunan batu, kemungkinan bangunan dari bata sudah dibuat.

$?-600 / 700$

Sebelum fase I, Ratu Boko tidak dihuni secara tetap, tetapi setidaknya kaum tani dan pemburu pernah menetap di situ dan salah satu di antaranya pernah meninggalkan kapak batu yang dalam survei pendahuluan pernah ditemukan. 


\section{$\mathbf{Y}$ uwono Sri Suwito, 1993, "Perencanaan Masterplan Situs Ratu Boko", dalam Pertemuan Teknis Dalam Rangka Evaluasi Program Pemugaran Situs Ratu Boko Yogyakarta 19-23 Juli 1993, 16 halaman.}

Pada tanggal 25 Oktober 1991, nama PT Taman Wisata Candi Borobudur dan Prambanan menjadi PT Taman Wisata Candi Borobudur, Prambanan dan Ratu Boko. Berbeda dengan pembentukan PT Taman Wisata Candi Borobudur dan Prambanan, yang telah didahului dengan selesainya Master Plan melalui penelitian yang dikenal dengan "Borobudur-Prambanan Archaeological Park", maka untuk kawasan Keraton Ratu Boko belum disusun Master Plan yang mendahului pemanfaatan kawasan ini sebagai obyek pariwisata.

Oleh karena itu perlu disusun Master Plan Ratu Boko dengan menyusun perencanaan tata ruang dan pemintakatan (zoning) situs. Perencanaan tata ruang mencakup kegiatan kepariwisataan dan non kepariwisataan dalam wadah fisik kawasan perencanaan. Selain itu juga menciptakan citra kawasan yang mendukung kegiatan tersebut, baik melalui artikulasi elemen-elemen fisik kawasan maupun suasana yang ditimbulkan oleh kehidupan keseharian warga setempat.

Strategi pemintakatan dengan memperhatikan wilayah amatan sebagai kawasankawasan yang masing-masing memiliki potensi dan masalah spesifik. Penetapan mintakat Situs Ratu Boko terdiri dari mintakat I (mintakat inti), mintakat II (mintakat penyangga), mintakat III (pengembangan).

Mintakat inti meliputi seluruh situs sebagai BCB yang akan dilindungi dan dipelihara. Situs yang sudah ditemukan pada wilayah seluas kurang lebih 500 X 500 meter yang terletak di puncak Bukit Boko, mencakup lingkungan gapura, lingkungan Pendopo (termasuk Keputren), dan lingkungan Gua.

Mintakat II atau mintakat penyangga merupakan mintakat yang secara langsung berbatasan dengan mintakat inti, dan diperuntukan bagi pengembangan kegiatan serta fasilitas wisata dengan peraturan dan pembatasan tertentu yang mendukung pelestarian dan pemanfaatan situs. Mintakat penyangga ini terdiri dari mintakat penyangga intensif dan mintakat penyangga ekstensif. Mintakat penyangga intensif merupakan mintakat dengan fasilitas dan penataan yang mendukung langsung kegiatan wisata di mintakat inti. Mintakat ini berada di bawah wewenang pengelolaan PT Taman Wisata Candi Borobudur, Prambanan dan Ratu Boko termasuk penguasaan hak atas tanah. Mintakat penyangga ekstensif mempunyai area yang lebih luas dan tidak dilengkapi dengan fasilitas khusus dengan penataan yang dilakukan secara sangat terbatas. Juga berada sepenuhnya pada PT Taman Wisata Candi Borobudur, Prambanan dan Ratu Boko. 
Mintakat III (mintakat pengembangan) merupakan mintakat sesudah mintakat penyangga. Di dalam mintakat ini ditetapkan sejumlah ketentuan yang bersifat umum, berlaku bagi struktur fisik maupun kegiatan di dalamnya, dengan tetap diarahkan pada dukungan bagi pengembangan mintakat-mintakat yang lebih dalam. Batas-batas mintakat pengembangan adalah:

- sebelah utara : jalan raya Yogya-Solo

- sebelah selatan: Jalan menuju Candi Ijo

- sebelah barat : Sungai Opak.

\section{KEPUSTAKAAN}

Bambang Prasetya Wahyuhono dan Wahyu Indrasana, 1993, "Lima Belas Tahun Pemugaran Situs Ratu Boko", dalam Pertemuan Teknis Dalam Rangka Evaluasi Program Pemugaran Situs Ratu Boko Yogyakarta, 15 halaman

Bernet Kempers, AJ. dan Soekmono, 1974, Candi-Candi di Sekitar Prambanan, Bandung: Ganaco N.V. (59 halaman)

Bosch, FDK, 1918, Rapporten Oudheidkundigen Dienst (ROD 1915), Weltevreden: Albrecht \& co. (hal 37-38).

Djoko Dwiyanto dan J. Susetyo Edy Yuwono, 1996. "Laporan Penelitian Arkeologi Kawasan Kraton Ratu Boko", Yogyakarta: Pusat Penelitian Pariwisata Univ. Gadjah Mada.

Dukut Santoso, 1993, "Rencana Pemugaran Situs Ratu Boko Selama Repelita VI" dalam Pertemuan Teknis Dalam Rangka Evaluasi Program Pemugaran Situs Ratu Boko Yogyakarta 19-23 Juli 1993, 22 halaman

Hari Untoro Drajat dan Ismijono, 1993. "Tinjauan Penanganan Situs Ratu Boko" dalam Pertemuan Teknis Dalam Rangka Evaluasi Program Pemugaran Situs Ratu Boko Yogyakarta, 9 halaman.

Kusen, nfn. (1995). Kompleks Ratu Boko: Latar Belakang Pemilihan Tempat Pembangunannya. Berkala Arkeologi, 15(3), 128-132. https://doi.org/10.30883/jba.v15i3.684

Rangkuti, Nurhadi, 1984 "Pemakaian Batu Tufa pada Candi-Candi di Sekitar Prambanan" Skripsi S1 Arkeologi, Fakultas Sastra Universitas Indonesia. 
Kusen, nfn. (1995). Kompleks Ratu Boko: Latar Belakang Pemilihan Tempat

Pembangunannya. Berkala Arkeologi, 15(3), 128-132. https://doi.org/10.30883/jba.v15i3.684

Rangkuti, Nurhadi, 1984 "Pemakaian Batu Tufa pada Candi-Candi di Sekitar Prambanan" Skripsi S1 Arkeologi, Fakultas Sastra Universitas Indonesia.

Soekmono, 1993, "Ratu Boko Quo Vadis?" dalam Pertemuan Teknis Dalam Rangka Evaluasi Program Pemugaran Situs Ratu Boko Y ogyakarta, 10 halaman

Subroto, Ph., 1993, "Kegiatan-Kegiatan Penelitian Situs Ratu Boko" dalam Pertemuan Teknis Dalam Rangka Evaluasi Program Pemugaran Situs Ratu Boko Yogyakarta 19-23 Juli 1993, 31 halaman

Teguh Asmar dan Bennet Bronson, 1973, Laporan Ekskavasi Ratu Baka 1973, Jakarta:

Lembaga Purbakala dan Peninggalan Nasional dan The University of Pennsylvania Museum.

Yuwono Sri Suwito, 1993, "Perencanaan Masterplan Situs Ratu Boko", dalam Pertemuan Teknis Dalam Rangka Evaluasi Program Pemugaran Situs Ratu Boko Yogyakarta 19-23 Juli 1993, 16 halaman. 